UDC 78.071.1(477):070.48(477)

DOI 10.24919/2519-058X.21.246919

\title{
Halyna NAMACHYNSKA
}

PhD (Philology), Associate Professor of Linguistic and Intercultural Communication Department, Istitute of Foreign Languages Drohobych Ivan Franko State Pedagogical University, 24 Ivan Franko Street, Drohobych, Ukraine, postal code 82100 (fokysnam@ukr.net)

ORCID: 0000-0002-2984-8422

\section{Lesia PERKHUN}

PhD (Education), Chief of Scientific Research Sector Drohobych Ivan Franko State Pedagogical University, 24 IvanFranko Street, Drohobych, Ukraine, postal code 82100 (lesiaperkhun@gmail.com)

ORCID: 0000-0001-9531-1175

ResearcherID: 1796208/lesia-perkhun/

\section{Галина НАМАЧИНСЬКА}

кандидатка філологічних наук, дочентка кафедримовноїта міжкультурної комунікачії інституту іноземних мов Дрогобицького державного педагогічного університету імені Івана Франка, Україна, вул. Івана Франка, 24, м. Дрогобич, Украӥна, індекс 82100 (fokysnam@ukr.net)

\section{Леся ПЕРХУН}

кандидатка педагогічних наук, начальник науково-дослідного сектора Дрогобиџького державного педагогічного університету імені Івана Франка, Україна, вул. Івана Франка, 24, м. Дрогобич, Україна, індекс 82100 (lesiaperkhun@gmail.com)

\section{NEWSPAPER JOURNALISM OF OSTAP NYZHANKIVSKY, A COMPOSER, A TEACHER, A PUBLIC ACTIVIST (1863 - 1919) \\ (review of the monograph: Molchko U. Newspaper Word of Father Ostap Nyzhankivsky. Stryi: TOV “Publishing House "Ukrpol”, 2021. 328 p.)}

\section{ГАЗЕТНА ПУБЛІЦИСТИКА КОМПОЗИТОРА, ПЕДАГОГА, ГРОМАДСЬКОГО ДІЯЧА ОСТАПА НИЖАНКІВСЬКОГО (1863 - 1919)} (рецензія на монографію: Молчко У. Газетне слово отця Остапа Нижанківського. Стрий: ТОВ “Видавничий дім "Укрпол”, 2021. 328 с.)

Recently, a monograph has been published on the journalistic work of Fr. Ostap Nyzhankivsky, the famous Galician composer and public figure (1863 - 1919). Its author is Ulyana Molchko, an associate professor at Drohobych Ivan Franko State Pedagogical University, who has been researching the multifaceted activities of the priest for a long time. It should be noted that other researchers, in particular Ya. Kolodiy, also wrote about Ostap Nyzhankivsky as a composer (Kolodiy, 1994), R. Soviak (Sov'iak, 2019). In contrast to previous works, which only outline the main journalistic heritage of the priest briefly, 
U. Molchko found, analyzed and published almost all journalistic articles by O. Nyzhankivsky, who during the second half of the XIXth - the first decades of the XXth century was one of the leading representatives of the Ukrainian intelligentsia of Galicia and carried out largescale educational work among the Ukrainian peasantry of that period.

The monograph consists of five chapters and appendices, which contain journalistic materials of O. Nyzhankivsky. In Chapter I, the author tried to elucidate the "worldview" of O. Nyzhankivsky as a journalist. The researcher declares the priest's "Ukrainocentrism" to be the defining worldview constant. It should be noted that this statement may immediately seem somewhat contradictory taking into consideration the affiliation of O. Nyzhankivsky to the Greek Catholic clergy. U. Molchko, seeking to highlight the fundamental principles of the worldview of the historical figure under analysis, naturally analyzes his upbringing and education in a family environment. She notes that O. Nyzhankivsky was born on January 24, 1863 in Stryi in the family of a Greek Catholic priest, where "dedication to the service of God was laid down by previous generations" (Molchko, 2021, p. 16). Having characterized of O. Nyzhankivsky's family, the researcher calls the Greek Catholic clergy "the Ukrainian advanced class". Undoubtedly, the leaders of the Ukrainian national revival in the Ukrainian lands of the Habsburg Empire in the XIXth century were mostly representatives of the Greek Catholic clergy. However, it should be acknowledged that a significant part of this clergy was Polonized, came from Polonized Russian noble families, spoke Polish at home. In the middle and second half of the XIXth century the Greek Catholic clergy in the dominance of the ideas of Romanticism, seeking to find and emphasize their own national identity, took the position of Russophilia, and later - Muscovite. Russophile ideas were widespread among the vast majority of the Greek Catholic clergy of Galicia under the Austrian rule. Therefore, we consider it somewhat incorrect to cite in the monograph A. Rudnytsky's unscientific statement about the Ukrainian priestly families as a "treasury" where the traditions of the Ukrainian nobility developed (Molchko, 2021, p. 17).

Of course, it cannot be taken into consideration that some Greek Catholic priests held the position of Galician representatives and defended their own Ukrainian identity. But in the monograph we did not see evidence that such views dominated the family in which O. Nyzhankivsky grew up. However, U. Molchko proves O. Nyzhankivsky's Ukrainocentrism in his adulthood by emphasizing the priest's participation in the Ukrainian social and cultural life of Galicia and Dnieper Ukraine, emphasizing his friendly relations with famous Ukrainian figures Anatol Vakhnianyn, Ivan Franko, and Kyrylo Studynsky, Mykola Lysenko. In addition, the author speaks of "Fr. O. Nyzhankivsky's contribution to building the foundations of the Ukrainian state". By stating this she means the participation of the priest in the organization of the dairy unions, cooperatives and credit unions of the Raiffeisen system in Stryi region, as well as participation in the establishment of youth branches of the societies "Falcon" and "Sich" in the villages of the same county (Molchko, 2021, pp. 23-24). In addition, O. Nyzhankivsky was a co-organizer (together with a lawyer Yevhen Olesnytsky) of the socio-political organization "Pidhirska Rada", the representatives of which defended the rights of the Ukrainians in Stryi region. At the begnning of the XXth century the priest became the head of Stryi district school council and advocated the formation of classes in the state gymnasium of Stryi with the Ukrainian language of instruction. At the beginning of August of 1914, he was present during the military oath of the Ukrainian Sich Riflemen and blessed this military formation, which participated in World War I as the military unit of the Austro-Hungarian Army. In November of 1918, O. Nyzhankivsky became an official of the 
Western Ukrainian People's Republic and headed the county Ukrainian National Council in Stryi region. As a composer O. Nyzhankivsky turned to the Ukrainian folklore, founded the societies for singing (Molchko, 2021, pp. 25-28). In general, the author proved that during his public activity O. Nyzhankivsky protected the Ukrainian national positions. However, we consider the term "Ukrainocentrism" not very proper.

In Chapter II “Origins of Fr. Ostap Nyzhankivsky's Newspaper Activity” U. Molchko intended to point out and analyze the first newspaper publications of Ostap Nyzhankivsky, published during his studies at Lviv Theological Seminary. However, in this small chapter the author writes about only one article by O. Nyzhankivsky - "In Memory of Denys Leontovych on the First Anniversary of his Death" (Molchko, 2021, pp. 31-35). This article appeared in the Lviv magazine "Zoria" in 1888 and was dedicated to the biography of a young Ukrainian pianist and composer Denys Leontovych, who died prematurely at the age of 21 . The author partly analyzes and partly retells the content of this article, emphasizing O. Nyzhankivsky's thoughts on the talent of artists and his critical analysis of D. Leontovych's waltz "Souvernir". In our opinion, it is not entirely justified to extend the description of one article to the boundaries of the entire chapter of the monograph.

The author devoted Chapter III exclusively to O. Nyzhankivsky's musicological journalism. It is known that since 1889 the young composer became an active contributor to the Ukrainian daily newspaper "Dilo", writing in its columns about various artistic events in Galicia. Thus, he announced and described the "artistic journey" of Lviv students to different cities of the region, often covered the concerts of the youth choir "Dvanadtsiatka" ("Twelve"), (which he headed), reported on the publication of collections of the Ukrainian carols, formation and activity of the choir "Lviv Boyan", events initiated by Ivan Franko "Committee for the Systematic Collection and Publication of Folk Songs", etc. A significant part of O. Nyzhankivsky's journalistic publications is devoted to the activities of worldfamous Ukrainian singers: Solomiya Krushelnytska, Oleksandr Myshuha, Mykola Levytsky. The contributor, for many years, reported honestly on the production of operas and concerts at the stage of Lviv Theater with the participation of these artists. In 1910, he published an article in the newspaper "Dilo" about the Ukrainian National Theater in Berezhany under the direction of Yosyp Stadnyk, a well-known theater director.

Analyzing some of these publications, U. Molchko resorted to internal criticism of sources (the publications of O. Nyzhankivsky), in particular, she tried to find out the motives of the author, to outline his character traits. Thus, speaking of a short journalistic article by O. Nyzhankivsky "Invitation" (1892), in which the composer invited Galician vocalists to take part in the concert on the occasion of the planned visit to Lviv of the Emperor of AustriaHungary Franz Joseph I, the author of the monograph wrote the following: "The elevated tone of the publicist in addressing the singers highlights the traits of his character, which are a keen sense of civic and professional duty. He treats each member of the choir with respect, that is why, he publishes a detailed list of priests and students of the seminary, which includes 57 people, and encourages them to take part in the dress rehearsal..." (Molchko, 2021, p. 46). We believe that $\mathrm{O}$. Nyzhankivsky's presentation of the entire list of the choir could have had other motives, not only "respect for each member of the choir". However, in this case, any statement will be hypothetical.

In Chapter IV - "Musical Life of Lviv at the End of the XIXth - the Beginning of the XXth Centuries in the Reviews of Fr. Ostap Nyzhankivsky" - U. Molchko gives the most accentuated reviews of the composer. Thus, O. Nyzhankivsky published a number of reviews 
of concerts of the Polish choir "Liutnia" and the Ukrainian choir "Stryisky Boyan", for opera performances in Lviv in 1895 ("Manon Lescaut" by Giacomo Puccini and "La Traviata" by Giuseppe Verdi), to the choral oratorio of Mechyslav Soltys "The Oath of Jan-Kazim", to the concert in Kyiv on the occasion of the 35th anniversary of Mykola Lysenko's creative activity (1903), to the concert of sacred music in Lviv (1904) and other artistic events. Many of O. Nyzhankivsky's works are dedicated to concerts and celebrations on the anniversaries of Taras Shevchenko and Markiyan Shashkevych, in which the composer analyzed the performance of each singer or choir and the performance of a particular song. At the same time, U. Molchko gives a description and some analysis of O. Nyzhankivsky's review of the collection of the Ukrainian songs "Nasha Duma", which was collected and published by Filaret Kolessa (Molchko, 2021, pp. 63-65). In general, in this chapter the author makes many quotations from the extensive reviews of O. Nyzhankivsky, often giving musicological characteristics to the composer's critical remarks.

Chapter V of the monograph deals with public, cultural and educational journalism of O. Nyzhankivsky. The author of the monograph mostly names and characterizes the articles of O. Nyzhankivsky, which deal with the establishment of the dairy unions in Stryi region, the formation of the "Regional Economic and Dairy Union", the "People's Meetings" in Stryi. U. Molchko focused considerable attention on the article of a public figure about the founding of the Ukrainian gymnasium in Stryi, calling this publication "a reflection of the struggle of the Galician intelligentsia (obviously, the Ukrainian intelligentsia in Galicia. - Auth.) for the establishment of the Ukrainian language of instruction in educational institutions, including gymnasiums" (Molchko, 2021, p. 113). The article contains a petition of the Ukrainian public of Stryi region to the Regional Skin Council in Lviv, in which, appealing to the Ukrainian population of the county, O. Nyzhankivsky asked for the opening of parallel Ukrainian classes in Stryi State gymnasium. The author notes rightly that similar petitions were sent to the Regional School Council by representatives of the Ukrainian community in other counties, including Drohobych, although without any success. Unfortunately, U. Molchko does not explain the reasons for the "failure" of the Ukrainians' demands for the establishment of public schools with Ukrainian as the language of instruction.

No less widely, with long quotations, U. Molchko presents another article by O. Nyzhankivsky - "Feast of the Presentation of the Sich Banner" (1912). In the report there is written about the solemn meeting of the youth sports organizations "Sich" and "Falcon", which took place on July 28, 1912. The author emphasizes again that such articles reflected the worldview of O. Nyzhankivsky, a composer, a teacher and a public figure (Molchko, 2021, pp. 116-118).

In general, we can fully agree with the researcher that the journalism of O. Nyzhankivsky is an important and valuable source for the history of the Ukrainian social and cultural and artistic life of Galicia at the end of the XIXth - the beginning of the XXth centuries. In the second part of the monograph U. Molchko published 42 newspaper articles by O. Nyzhankivsky, classifying them according to a chronological order. In addition, she compiled a bibliographic index of the priest's publications, which contains 44 items.

Along with the positive assessment of the work of V. Molchko, we note some shortcomings. The structuring of the monograph does not seem to be thought out well. In Chapter II on "the origins of the newspaper activity" of O. Nyzhankivsky it would be appropriate to describe not only the article about D. Leontovych, but also other articles written by the young artist during his studies at Lviv Theological Seminary. We believe that the third and fourth chapters should be combined, as both deal with musical life in Lviv at the end of the XIXth - the 
beginning of the XXth centuries. The author should have used Natalia Kolb's monograph on the Greek Catholic parish clergy in Galicia in the 90s of the XIXth century (Kolb, 2015).

U. Molchko collected and edited O. Nyzhankivsky's articles published in the periodicals "Zoria", "Dilo" (Lviv), "Pidhirska Rada", "Hospodar i Promyslovets" (Stryi), but she did not indicate that the bibliography of the press publications of the historical figure is complete. We assume that O. Nyzhankivsky was published in the magazine "Stryi Visnyk" - the body of the county commissariat of Stryi region in 1918 - 1919. It is known that on November 15, 1918 the priest, as a representative of Stryi County Council, made a report on the situation in the region at the meeting of Parliament of the Western Ukrainian People's Republic - the Ukrainian National Council in Lviv (Velykochyi, 2003, pp. 184, 187). It is possible that some aspects of this report were published in the magazine.

Thus, the monograph by U. Molchko deserves attention of researchers of the views and activities of the Ukrainian intelligentsia, cultural, educational and socio-political life of Galicia at the end of the XIXth - the beginning of the XXth centuries. For the first time, in the monograph there are collected rare works of the artist, the teacher and a public figure, which reflect the panorama of cultural and social development of Galicia at the turn of two centuries.

\section{BIBLIOGRAPHY}

Kolb, N. (2015). "Z Bohom za Tserkvu i Vitchyznu”: hreko-katolytske parafialne dukhovenstvo $v$ Halychyni u 90-kh rr. XIX stolittia ["With God for the Church and the Fatherland": the Greek Catholic Parish Clergy in Galicia in the 90s of the XIXth century]. Zhovkva: Misioner, 372 p. [in Ukrainian]

Kolodii, Ya. (1994). Ostap Nyzhankivskyi [Ostap Nyzhankivsky]. Lviv: Lohos, 64 p. [in Ukrainian]

Molchko, U. (2021). Hazetne slovo ottsia Ostapa Nyzhankivskoho [Newspaper Word of Father Ostap Nyzhankivsky]. Stryi: TOV "Vydavnychyi dim "Ukrpol”, 328 p. [in Ukrainian]

Sov'iak, R. (2019). Ostap Nyzhankivskyi [Ostap Nyzhankivsky]. Stryi: Shchedryk, 256 p. [in Ukrainian]

Velykochyi, V. S. (2003). Dzherela do vyvchennia derzhavnoho budivnytstva v ZUNR [Sources for the Study of State Building in the ZUNR]. Ivano-Frankivsk: Plai, 278 p. [in Ukrainian]

The article was received February 11, 2021. Article recommended for publishing 24/11/2021. 